\title{
Breast cancer stem cells expressing different stem cell markers exhibit distinct biological characteristics
}

\author{
$\mathrm{JUN} \mathrm{SHAO}^{1,2^{*}}$, WEI FAN $^{2 *}, \mathrm{BIAO} \mathrm{MA}^{2}$ and YIPING WU ${ }^{1}$ \\ ${ }^{1}$ Department of Plastic Surgery, Wuhan Tongji Hospital, Wuhan, Hubei 430030; \\ ${ }^{2}$ Department of Breast Cancer, Hubei Cancer Hospital, Wuhan, Hubei 430079, P.R. China
}

Received September 25, 2015; Accepted September 12, 2016

DOI: $10.3892 / \mathrm{mmr} .2016 .5899$

\begin{abstract}
Identification and isolation of breast cancer stem cells (CSCs) based on CD44/CD24 expression and/or enzymatic activity of aldehyde dehydrogenase 1 (ALDH1). However, the differences among the $\mathrm{CD} 44^{+} / \mathrm{CD} 24^{-/ \text {low }}$ cells, $\mathrm{ALDH} 1^{+}$cells and the overlap between the sub-populations have not been frequently investigated. Thus, it is imperative to improve the understanding of breast CSC with different stem markers. $\mathrm{CD} 44^{+} / \mathrm{CD} 24^{- \text {llow }}, \mathrm{ALDH}^{+}$and $\mathrm{ALDH} 1^{+} \mathrm{CD} 44^{+} / \mathrm{CD} 24^{-/ \text {low }}$ cell populations were isolated from fresh breast cancer tissues and analyzed by flow cytometry and immunofluorescence. Mammosphere formation, cell proliferation assay and Transwell experiments, were used to analyze self-renewal, proliferation and invasion, respectively, for each sub-population. Finally, in vivo experimentation in mice was performed to evaluate the tumorigenic abilities of the sub-populations. The sub-populations of $\mathrm{CD} 44^{+} / \mathrm{CD} 24^{-/ \text {low }}$, ALDH $1^{+}$and $\mathrm{ALDH} 1^{+} \mathrm{CD} 44^{+} / \mathrm{CD} 24^{-/ \text {low }}$ in human breast cancer cells, represented the 7.2, 4.6 and $1.5 \%$ of the total tumor cell population, respectively. $\mathrm{ALDH} 1^{+} \mathrm{CD} 44^{+} / \mathrm{CD} 24^{- \text {llow }}$ cells had the strongest ability of self-renewal, invasion, proliferation and tumorigenicity compared with the other sub-populations $(\mathrm{P}<0.05)$. In conclusion, different phenotypes of $\mathrm{CD} 44^{+} / \mathrm{CD} 24^{- \text {llow }}, \mathrm{ALDH} 1^{+}$ and $\mathrm{ALDH} 1^{+} \mathrm{CD} 44^{+} / \mathrm{CD} 24^{- \text {llow }}$ were isolated and demonstrated that breast CSCs are heterogeneous, and they exhibit distinct biological characteristics. As ALDH1 ${ }^{+} \mathrm{CD} 44^{+} / \mathrm{CD} 24^{-/ \text {low }}$ cells demonstrated the strongest stem-like properties, it may be a useful specific stem cell marker. The utilization of more reliable biomarkers to distinguish the breast CSC pool will be important for the development of specific target therapies for breast cancer.
\end{abstract}

Correspondence to: $\mathrm{Dr}$ Yiping $\mathrm{Wu}$, Department of Plastic Surgery, Wuhan Tongji Hospital, 1095 Jie Fang Avenue, Wuhan, Hubei 430030, P.R. China

E-mail: 39390822@qq.com

*Contributed equally

Key words: breast cancer, aldehyde dehydrogenase 1, biological characteristics, $\mathrm{CD} 44^{+} / \mathrm{CD} 24^{-/ \text {low }}$

\section{Introduction}

Breast cancer is the most common cancer in women world wide (1). Although significant progress has been made in early diagnosis and treatment, metastasis cannot be prevented in certain patients. Therefore, breast cancer remains a major public health burden. There is accumulating evidence that cancer stem cells (CSCs) are responsible for tumor initiation, maintenance, invasion, heterogeneity, metastasis and therapy resistance $(2,3)$. In breast cancer, $\mathrm{CD} 44^{+} / \mathrm{CD} 24^{-/ \text {low }}$ is the first convincing marker for identifying and isolating tumorigenic CSCs from non-tumorigenic cancer cells.

Aldehyde dehydrogenase 1 (ALDH1) is a detoxifying enzyme that is associated with the stemness-associated markers, octamer binding transcription factor 4 and Polycomb complex protein BMI-1, and is proven to be a marker of stem/progenitor cells in neural and hematopoietic systems and in the mammary gland (4). Ginestier et al (4) demonstrated that breast cancer cells with increased ALDH activity exhibit stem/progenitor cell properties. It was previously demonstrated that using ALDH1 as a breast CSC marker can further divide the $\mathrm{CD} 44^{+} / \mathrm{CD} 24^{- \text {-low }}$ cell population into fractions that are tumorigenic (4-7).

However, within breast cancer cells cultured from fresh human specimens, few studies have analyzed the details of the biological characteristic differences between $\mathrm{CD} 44^{+} / \mathrm{CD} 24^{- \text {/low }}$ phenotype and high ALDH1 activity cells. Based on this current knowledge, there is evidence to support the hypothesis that the combining CD44/CD24 cell surface expression with ALDH1 activity may be a more accurate method to identify and isolate CSC-like cells within a population of breast cancer cells. Furthermore, it is imperative to improve the understanding of the biological differences among breast CSCs that express different stem cell markers.

The CSC hypothesis has important implications for understanding the basic biology of tumorigenesis. Cells endowed with stem-like properties demonstrate self-renewal and high tumorigenic potential. Current cancer treatments based on tumor regression can kill differentiated tumor cells, while sparing the small CSC population (8). Therefore, the development of more effective cancer therapies may require the targeting, identification, isolation and characterization of CSCs.

In the present study, breast cancer cells from fresh specimens were cultured and the percentage of three different sub-population cells with $\mathrm{CD} 44^{+} / \mathrm{CD} 24^{-/ \text {low }}, \mathrm{ALDH}^{+}$, and 
$\mathrm{ALDH} 1^{+} \mathrm{CD} 44^{+} / \mathrm{CD} 24^{-/ \mathrm{low}}$ phenotypes were analyzed. Additionally, the self-renewal, proliferative, invasive ability of these cells was analyzed in vitro. Finally, the capacity of these cells to generate de novo tumors was also investigated in an in vivo mouse model.

\section{Materials and methods}

Dissociation and primary culture of breast cancer cells. Samples of fresh breast cancer specimens were obtained surgically from the primary tumor of one 32-year-old female patient. The samples were dissociated mechanically and enzymatically, based on the triple negative and basal-like pathological type. The samples were dissociated mechanically and enzymatically, based on pathological types that were triple negative and basal-like. No treatment (chemotherapy or endocrine therapy) was given to the patients before the operation and they were treated at the Hubei Cancer Hospital (Wuhan, China) in 2014. Breast cancer cell isolation was performed as previously described (9). The biological specimens were utilized according to the approved institutional review board protocols for research in human subjects. The study was approved by the ethical committee of Wuhan Tongji Hospital (Wuhan, China). All patients provided written informed consent prior to participation in the present study.

Mammosphere suspension culture. Mammosphere culture was performed as previously described (10). Cells from one 32-year-old patient were cultured at $37^{\circ} \mathrm{C}$ and $5 \% \mathrm{CO}_{2}$ a density of 20,000 viable cells $/ \mathrm{ml}$ in primary culture in serum-free Dulbecco's modified Eagle's medium (DMEM)-F12 medium (Sigma-Aldrich; Merck Millipore, Darmstadt, Germany), which was changed every 2 days. The daily morphological changes of mammospheres were observed under a light microscope. Passaging was performed after 5 days at a density of 5,000 cells $/ \mathrm{ml}$.

Immunofluorescence to identify cell phenotype. The procedure was performed as previously described (4). The main steps were as follows: i) Cell preparations, ii) fixation, iii) permeabilization, iv) primary antibody incubation (mouse anti-human CD44, cat. no. BM0321; mouse anti-human CD24, cat. no. BM1723; ALDH1, cat. no. BM3672; Wuhan Boster Biological Technology, Ltd., Wuhan, China), v) secondary antibody incubation [goat anti-mouse IgG phycoerythrin (PE), cat. no. BA1031; rabbit anti-mouse IgG-fluorescein isothiocyanate, cat. no. BA1101; Wuhan Boster Biological Technology, Ltd.], vi) mounting and vii) imaging.

Flow cytometry. The procedure was performed according to the method of Al-Hajj et al (11). The cells were collected by centrifugation, trypsin was added for digestion, serum-free medium was added to terminate the digestion, and a single-cell suspension was obtained. Test tube and control tube were set to adjust the cell concentration, and the number of cells was $\geq 1 \times 10^{5}$. Anti-human CD44-phycoerythrin (PE) CY5 (15-0441-81) and anti-human CD24-PE (12-0241-81) antibodies (eBioscience, Inc., San Diego, CA, USA) were added to the test tube, while isotype control antibody was added to the control tube, mixed and incubated at room temperature in the dark for $30 \mathrm{~min}$. Samples were washed twice with PBS, the supernatant was discarded after centrifugation at $200 \mathrm{x} g$ for $5 \mathrm{~min}$ at room temperature, and the cells were resuspended in PBS containing 1\% paraformaldehyde to fix the cells. Finally, $300 \mu 1$ PBS was added. The analysis was performed using a FACStarPLUS (BD Biosciences, Franklin Lakes, NJ, USA) flow cytometer.

The ALDEFLUOR kit (Stemcell Technologies, Inc., Vancouver, BC, Canada) was used to isolate the cell population with a high ALDH enzymatic activity. Cells were suspended in serum-free DMEM-F12 medium. ALDEFLUOR assay buffer containing activated ALDEFLUOR substrate (BAAA; $1 \mu \mathrm{mol} / 1$ per $1 \times 10^{6}$ cells) was added to the cell suspension, mixed and incubated at $37^{\circ} \mathrm{C}$ for $30 \mathrm{~min}$. The cell suspension was centrifuged, washed with PBS and re-suspended in DMEM-F12 serum-free medium. Then cells were diluted using ALDEFLUOR buffer, adjusting the cell concentration to $1 \times 10^{6}$ cells $/ \mathrm{ml}$. The flow cytometry detection was immediately performed or performed within $24 \mathrm{~h}$ at $4^{\circ} \mathrm{C}$.

To isolate the $\mathrm{ALDH} 1^{+} \mathrm{CD} 44^{+} / \mathrm{CD} 24^{-/ \text {low }}$ cells, $\mathrm{CD} 44^{+} / \mathrm{CD} 24^{-/ \text {low }}$ cells were suspended $\left(1 \times 10^{6}\right.$ cells $\left./ \mathrm{ml}\right)$ in in ALDEFLUOR assay buffer and $5 \mu \mathrm{l} / \mathrm{ml}$ ALDEFLUOR substrate was added to the cell suspension. Then cells were separated as described above.

Analysis of proliferation using MTT. Each cell sub-population and cells in the control group (primary cells without sorting) were re-suspended in DMEM-F12 [1:1; $2 \%$ fetal bovine serum (FBS; Gibco Invitrogen; Thermo Fisher Scientific, Inc., Waltham, MA, USA); $20 \mathrm{ng} / \mathrm{ml}$ basic fibroblast growth factor; $20 \mathrm{ng} / \mathrm{ml}$ epidermal growth factor, $2 \%$ B27 and $1 \%$ penicillin-streptomycin], and cultured in $96-$-well plate (approximately $10^{3}$ cells/well, five wells/group), and then cultured at $37^{\circ} \mathrm{C}$. Culture medium $(25 \mu \mathrm{l})$ was added to each well every 2 days, the MTT assay was performed and the absorbance at $490 \mathrm{~nm}$ was measured using a microplate reader (Bio-Rad Laboratories, Inc., Hercules, CA, USA) every 24 h for consecutive 8 days to obtain a curve of the measured values.

Mammosphere formation ability assay. Mammosphere formation rate or cloning efficiency is an important indicator of tumor cell self-renewal ability. The experimental procedure used to compare the cloning efficiency of cells in each sub-population was as follows: A single cell suspension of each sub-population (after sorting) and a non-sorting cell suspension as a control group were re-suspended in serum-free medium containing growth factors $(20 \mathrm{ng} / \mathrm{ml}$ basic fibroblast growth factor and $20 \mathrm{ng} / \mathrm{ml}$ epidermal growth factor; BD Biosciences) to adjust the concentration to $10^{3}$ cells $/ \mathrm{ml}$, and were seeded in 96-well plates. Subsequently, 100 cells were seeded, $25 \mu 1$ medium containing growth factors was added to each well every 2 days, and breast cancer mammosphere numbers were counted in each well. Breast mammosphere formation rate is calculated as follows: Mammosphere (MS) $\%=$ microsphere number/inoculated cells $\times 100 \%$.

Invasion ability of cells in each sub-population by Transwell assay. The 24-well Transwell chambers $(8.0 \mu \mathrm{m})$ were placed 
into the culture plates, pre-warmed serum-free DMEM-F12 medium $(300 \mu \mathrm{l})$ was added to the chamber and incubated at room temperature for $30 \mathrm{~min}$, and then the medium was removed. The cell suspension was prepared to for experiments, digestion, and the supernatant was discarded following centrifugation and re-suspended with serum-free medium containing $0.2 \%$ bovine serum albumin (Gibco Invitrogen; Thermo Fisher Scientific, Inc.). A $200 \mu \mathrm{l}$ cell suspension $\left(1 \times 10^{5}\right.$ cells $\left./ \mathrm{ml}\right)$ was added to the Transwell chamber. Another $500 \mu 1$ DMEM-F12 medium containing 10\% FBS was added to the 24-well plate lower chamber, avoiding the formation of air bubbles. The suspension was incubated in a sterile incubator for $24 \mathrm{~h}$. Furthermore, Matrigel was added to coat the upper chamber, while $500 \mu \mathrm{l}$ complete medium (containing $0.5 \mathrm{mg} / \mathrm{ml} \mathrm{MTT}$ ) was added to the lower house of a 24-well plate, and incubated at $37^{\circ} \mathrm{C}$ for $4 \mathrm{~h}$ before chamber. Next, the chamber was immersed in $500 \mu \mathrm{l}$ dimethyl sulfoxide and incubated for $10 \mathrm{~min}$. The absorbance was measured on a microplate reader at a wavelength of $490 \mathrm{~nm}$.

In vivo tumorigenicity experiment. The animal experiments were approved by the ethics committee of Hubei Cancer Hospital (Wuhan, China). Female BALB/C-nude mice $(n=60$; specific-pathogen free; age, 4-6 weeks old; weight, 14-22 g) were purchased from Hunan Slack King of Laboratory Animal Co., Ltd. (Changsha, China). The mice were kept at a temperature of $20-26^{\circ} \mathrm{C}$ with a relative humidity of $40-70 \%$, with an average of $5 \mathrm{~g} / 100 \mathrm{~g}$ weight food and 6-7 ml/100 $\mathrm{g}$ weight water per day, with a light/dark cycle of $12 \mathrm{~h} / 12 \mathrm{~h}$. The mice were divided into three batches, and each batch contained four groups with five nude mice in each group. The four groups were represented by the control group, $\mathrm{CD} 44^{+} \mathrm{CD} 24^{-/ \text {low }}$ group, $\mathrm{ALDH}^{+}$group and $\mathrm{ALDH} 1^{+} \mathrm{CD} 44^{+} \mathrm{CD} 24^{-/ \text {low }}$ group. The tumorigenicity experiments were performed within a laminar flow cabinet. Unsorted primary cells were inoculated in the mice of the control group, while CD $44^{+} \mathrm{CD} 24^{-/ \text {low }}$ cells, $\mathrm{ALDH}^{+}$cells, and $\mathrm{ALDH} 1^{+} \mathrm{CD} 44^{+} \mathrm{CD} 24^{-/ \text {low }}$ cells were inoculated in the mice of the other three groups. The first batch of nude mice were injected with 500 cells per mouse in each group; the second batch was injected with 5,000 cells per mouse, and the third batch was injected with 50,000 cells per mouse. The method of Al-Hajj et al (11), was followed, including the following stages: i) Cell collection; ii) cell mixing; and iii) cell inoculation. A volume of $0.1 \mathrm{ml}$ of cells, was subcutaneously inoculated on one side of the chest of each mouse. Subsequently, the mice were fed under standard conditions for 8 weeks. Mice were monitored once a week, and the tumor dimension was measured and recorded. The mice were sacrificed by cervical dislocation after 8 weeks of monitoring.

Statistical analysis. The results were statistically analyzed using SPSS 13.0 (SPSS Inc., Chicago, IL, USA). The continuous variables are expressed as the mean \pm standard deviation. Categorical variables are expressed as frequencies and/or percentages. The data were compared by analysis of variance analysis and followed by least significant difference post hoc analysis. For two independent samples, a $t$-test was performed. $\mathrm{P}<0.05$ was considered to indicate a statistically significant difference.

\section{Results}

$C D 44^{+} \mathrm{CD} 24^{- \text {llow }}$ phenotype and ALDH1 activity in breast cancer cells. Flow cytometry analysis enables the separation of different cell populations. As demonstrated in the current study, the proportion of $\mathrm{ALDH} 1^{+}$cells in the breast cancer specimens was $4.6 \%$ (Fig. 1A), whereas $7.2 \%$ of the population were $\mathrm{CD} 44^{+} \mathrm{CD} 24^{-/ \text {low }}$ phenotype tumor cells (Fig. 1B). Further sorting of the cells by ALDEFLUOR was performed to isolate the population with high ALDH enzymatic activity; $20.8 \%$ of these cells were $\mathrm{CD} 44^{+} \mathrm{CD} 24^{-/ \text {low }}$ (Fig. 1C). A small overlap of the two groups, $\mathrm{ALDH} 1^{+} \mathrm{CD} 44^{+} \mathrm{CD} 24^{-/ \text {low }}$ sub-population, was represented by $1.5 \%$ of the total cells.

Difference in the mammosphere formation of different cells population. The sorted $\mathrm{CD} 44^{+} \mathrm{CD} 24^{- \text {llow }}, \mathrm{ALDH}^{+}$and $\mathrm{ALDH} 1^{+} \mathrm{CD} 44^{+} \mathrm{CD} 24^{-/ \text {low }}$ cells in each sub-population were suspended and cultured in serum-free medium. A few mammospheres was observed at 4-5 days, with a diameter of 20-30 $\mu \mathrm{m}$. Typical mature mammospheres of $\mathrm{CD} 44^{+} \mathrm{CD} 24^{-/ \text {low }}$ cells formed after $\sim 1$ week in culture, with a diameter of 80-100 $\mu \mathrm{m}$ (Fig. 2A). For the $\mathrm{ALDH}^{+}$and $\mathrm{ALDH} 1^{+} \mathrm{CD} 44^{+} \mathrm{CD} 24^{-/ \text {low }}$ cells, mammospheres were formed with an increased number and size in the following days (Fig. 2B and C), and remained stable and in shape until 10-12 days. Mammospheres occurred earliest in the $\mathrm{ALDH} 1^{+} \mathrm{CD} 44^{+} \mathrm{CD} 24^{-/ \text {low }}$ cells after 2 days in serum-free medium and exhibited the largest diameter; up to 110-120 $\mu \mathrm{m}$ (Fig. 2C). Additionally, $\mathrm{ALDH} 1^{+} \mathrm{CD} 44^{+} \mathrm{CD} 24^{- \text {-low }}$ cells exhibited the longest stability, starting to disintegrate later than the other sub-groups.

Immunofluorescence findings. Following the suspension of the unsorted primary cells in serum-free medium with growth factors for 7 days, mammospheres were collected, and corresponding fluorescent antibodies were added. Green fluorescence was detected in the cytoplasm of $\mathrm{ALDH} 1^{+}$ cell, with no staining in the membrane and the nucleus (Fig. 3B). CD $44^{+} \mathrm{CD} 24^{-/ \text {low }}$ cells exhibited brownish/red fluorescence, predominantly in the membrane, although cytoplasmic staining was observed in certain cells (Fig. 3C). Cells exhibiting green fluorescence in the cytoplasm and the brownish/red fluorescence in the membrane (Fig. 3D) indicated the presence of the $\mathrm{ALDH} 1^{+} \mathrm{CD} 44^{+} \mathrm{CD} 24^{-/ \text {low }}$ sub-population.

Differences in proliferation among the sub-populations. The cells were divided into four groups: Control cells (unsorted primary cells), $\mathrm{CD} 44^{+} \mathrm{CD} 24^{-/ \text {low }}, \mathrm{ALDH}^{+}$and $\mathrm{ALDH} 1^{+} \mathrm{CD} 44^{+} \mathrm{CD} 24^{-/ \text {low }}$ cells, using flow cytometry. The proliferation ability of cells in each sub-population was then compared. The number of living cells was subsequently measured by MTT assay (Fig. 4A). After 8 days of culture, the results demonstrated that $\mathrm{CD} 44^{+} \mathrm{CD} 24^{-/ \text {low }}$, $\mathrm{ALDH} 1^{+}$and $\mathrm{ALDH} 1^{+} \mathrm{CD} 44^{+} \mathrm{CD} 24^{-/ \text {low }}$ cells were continuously proliferating, with no observable of quiescence. On day 8 , the values of control, $\mathrm{CD} 44^{+} \mathrm{CD} 24^{-/ \text {low }}, \mathrm{ALDH} 1^{+}$ and $\mathrm{ALDH} 1{ }^{+} \mathrm{CD} 44^{+} \mathrm{CD} 24^{-/ \text {low }}$ cells were $0.160 \pm 0.005$, $0.251 \pm 0.005,0.259 \pm 0.007$ and $0.279 \pm 0.009$, respectively. The cell proliferation of the three sub-populations was significantly increased compared with the control group 

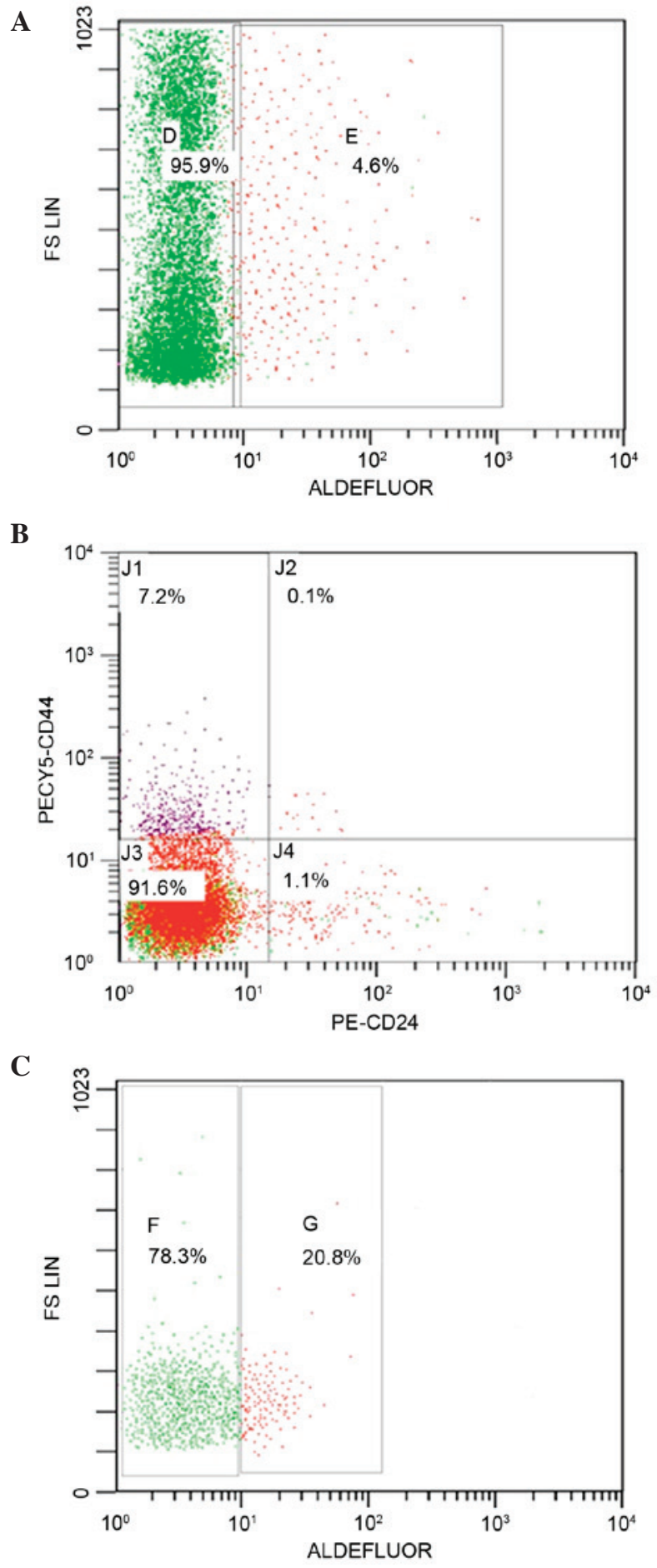

Figure 1. Flow cytometry sorting of tumor cells with different stem cel markers. The results demonstrate that (A) the percentage of ALDEFLUOR positive cells was $4.6 \%$, (B) the percentage of $\mathrm{CD} 44^{+} \mathrm{CD} 24^{- \text {/low }}$ cells was $7.2 \%$ and (C) $1.5 \%$ were $\mathrm{ALDH} 1^{+} \mathrm{CD} 44^{+} / \mathrm{CD} 24^{-/ 10 w}$ cells. ALDH1, aldehyde dehydrogenase 1 .

cells $(\mathrm{P}=0.0113$; Fig. 4A), however, there were no significant differences among the three sub-population groups $(\mathrm{P}=0.151)$.

Differences in invasion of each cell sub-population. To compare the invasion and migration ability of each cell group, Transwell experiments were conducted. After $48 \mathrm{~h}$ in culture, a large number of $\mathrm{CD} 44^{+} \mathrm{CD} 24^{-/ \text {low }}, \mathrm{ALDH} 1^{+}$ and $\mathrm{ALDH} 1^{+} \mathrm{CD} 44^{+} \mathrm{CD} 24^{-/ \text {low }}$ cells passed through the Transwell membrane. The MTT absorbance of the control group was $0.48 \pm 0.021$, and the $\mathrm{CD} 44^{+} \mathrm{CD} 24^{-/ \text {low }}, \mathrm{ALDH} 1^{+}$ and $\mathrm{ALDH} 11^{+} \mathrm{CD} 44^{+} \mathrm{CD} 24^{-/ \text {low }}$ groups were $1.05 \pm 0.058$, $1.11 \pm 0.036$ and $1.56 \pm 0.075$, respectively. The invasion and migration abilities of $\mathrm{CD} 44^{+} \mathrm{CD} 24^{-/ \text {low }}, \mathrm{ALDH}^{+}$, and $\mathrm{ALDH} 1^{+} \mathrm{CD} 44^{+} \mathrm{CD} 24^{- \text {llow }}$ cells were significantly increased compared with the control group $(\mathrm{P}=0.0129)$. Additionally, the invasion and migration abilities of $\mathrm{ALDH} 1^{+} \mathrm{CD} 44^{+} \mathrm{CD} 24^{- \text {/low }}$ cells were increased compared with the $\mathrm{CD} 44^{+} \mathrm{CD} 24^{-/ \text {low }}$ and $\mathrm{ALDH}^{+}$sub-populations ( $\mathrm{P}=0.0287$; Fig. 4B).

Differences in the mammosphere formation rate in each sub-population. At day 8 after suspension, the mammosphere formation rates were $4.80 \pm 1.10,35.70 \pm 1.92,41.50 \pm 1.71$ and $62.45 \pm 2.50 \%$ in the control group, $\mathrm{CD} 44^{+} \mathrm{CD} 24^{-/ \text {low }}, \mathrm{ALDH} 1^{+}$ and $\mathrm{ALDH} 1{ }^{+} \mathrm{CD} 44^{+} \mathrm{CD} 24^{-/ \text {low }}$ groups, respectively. The mammosphere formation rate was significantly increased in the three sub-populations groups compared with the control group $(\mathrm{P}<0.001)$. Additionally, the mammosphere formation rate of $\mathrm{ALDH} 1{ }^{+} \mathrm{CD} 44^{+} \mathrm{CD} 24^{-/ \text {low }}$ cells was significantly increased compared with the other two sub-populations $(\mathrm{P}=0.0185$; Fig. 4C).

Comparison of the tumorigenic ability of each sub-population in vivo. A nude mice tumorigenic experiment was performed to discover the tumorigenicity of the tumor cell sub-populations. Fig. 5A demonstrates a nude mouse bearing a tumor developed following injection of $\mathrm{ALDH}^{+} \mathrm{CD} 44^{+} \mathrm{CD} 24^{-/ \text {low }}$ sub-population cells. The batch of nude mice that received an injection of 500 cells of the unsorted control cells, $\mathrm{CD} 44^{+} \mathrm{CD} 24^{-/ \text {low }}$ and $\mathrm{ALDH}^{+}$sub-populations exhibited no tumor formation after 8 weeks. However, mice that received an injection of $500 \mathrm{ALDH}^{+} \mathrm{CD} 44^{+} \mathrm{CD} 24^{-/ \text {low }}$ sub-population cells demonstrated clear and palpable subcutaneous nodules by week 6 , reaching a size of up to $0.36 \pm 0.07 \mathrm{~cm}$ at week 8 , (Fig. 5B). The second batch of nude mice that received an injection of 5,000 cells of the $\mathrm{CD} 44^{+} \mathrm{CD} 24^{-/ \text {low }}$ sub-population exhibited tumor development from the week 6 onward. Nude mice that received an injection of 5,000 cells of the ALDH1 ${ }^{+}$ sub-population exhibited tumor development from week 5 onward, and finally, nude mice that received an injection of 5,000 cells of the ALDH+CD $44^{+} \mathrm{CD} 24^{-/ \text {low }}$ sub-population exhibited tumor development from week 2 onward (Fig. 5C). The tumor lengths at week 8 were $0.25 \pm 0.04,0.45 \pm 0.05$ and $0.97 \pm 0.06 \mathrm{~cm}$ in the $\mathrm{CD} 44^{+} \mathrm{CD} 24^{-/ \text {low }}, \mathrm{ALDH}^{+}$and ALDH ${ }^{+} \mathrm{CD} 44^{+} \mathrm{CD} 24^{-/ \text {low }}$ sub-populations, respectively. Statistical analysis demonstrated that the tumorigenic abilities of the cells in the three sub-populations were significantly increased compared with the control group. The $\mathrm{ALDH}^{+} \mathrm{CD} 44^{+} \mathrm{CD} 24^{-/ \text {low }}$ sub-population exhibited the strongest ability of tumor formation and the tumor length was significantly increased compared with the other sub-populations $(\mathrm{P}=0.0162$; Fig. $5 \mathrm{C})$. The third batch of nude mice that received an injection of 50,000 cells of the $\mathrm{ALDH}^{+} \mathrm{CD} 44^{+} \mathrm{CD} 24^{-/ \text {low }}$ sub-populations exhibited tumor formation from the week 1 onward, with a fast growth and a large tumors developing (Fig. 5D). Nude mice that received an injection of 50,000 cells of the $\mathrm{ALDH}^{+}$ and of the $\mathrm{CD} 44^{+} \mathrm{CD} 24^{-/ \text {low }}$ sub-populations exhibited 
A

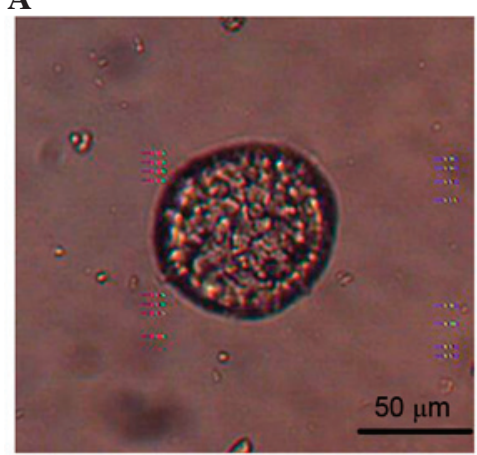

B

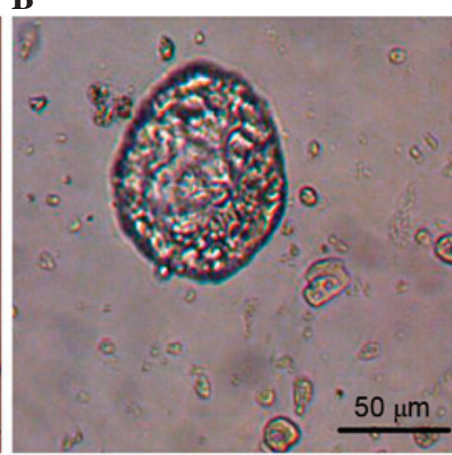

C

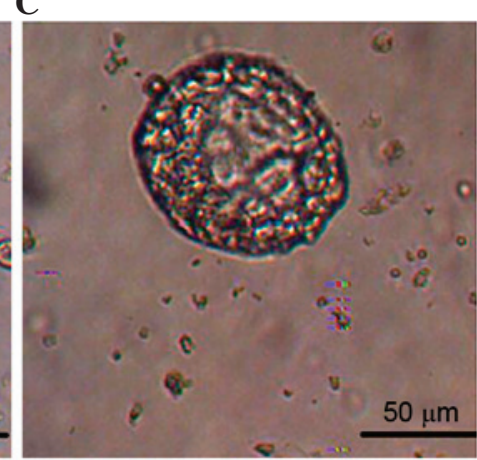

Figure 2. Mammosphere formation by different subgroups of tumor cells. Cell were imaged using light microscopy (magnification, $\mathrm{x} 400$ ). (A) Mammosphere was formed and differentiated to a mature mammoshpere of $80 \mu \mathrm{m}$ after 7 days (CD $44^{+} \mathrm{CD} 24^{-/ \mathrm{low}}$ mammoshpere). Typical mammoshpere formation by (B) $\mathrm{ALDH} 1^{+}$and $(\mathrm{C}) \mathrm{ALDH1} 1^{+} \mathrm{CD} 44^{+} \mathrm{CD} 24^{- \text {llow }}$ cells. ALDH1, aldehyde dehydrogenase 1.

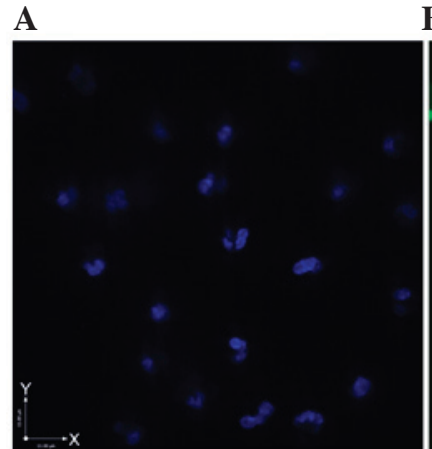

B

C

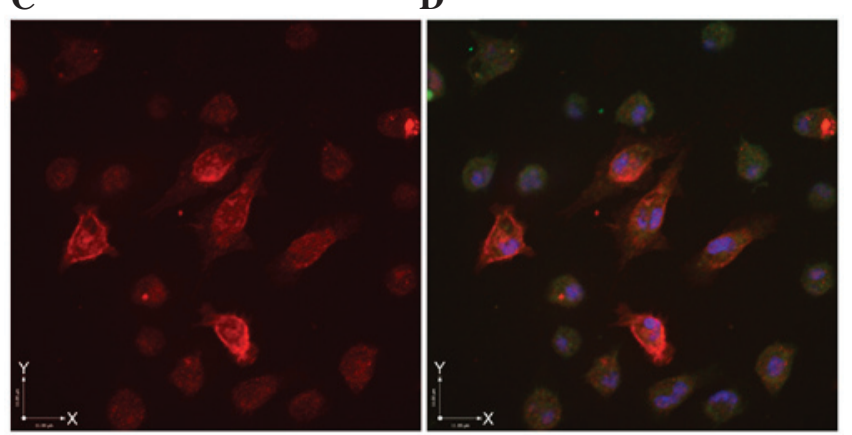

Figure 3. Immunofluorescence detection of breast cancer cells with different stem cell marker by laser confocal microscopy. (A) DAPI stained nuclei. (B) $\mathrm{ALDH} 1^{+}$cells exhibited green fluorescence in the cytoplasm. (C) $\mathrm{CD} 44^{+} \mathrm{CD} 24^{-/ \text {low }}$ cells were exhibited brownish/red fluorescence in the membrane, with some cells showing cytoplasmic fluorescence. (D) $\mathrm{ALDH} 1^{+} \mathrm{CD} 44^{+} \mathrm{CD} 24^{-/ \text {low }}$ cells exhibited brownish/red fluorescence in the membrane and green fluorescence in the cytoplasm. ALDH1, aldehyde dehydrogenase 1 .

tumor formation from week 4 onward, and at week 8 , the tumor lengths were $2.10 \pm 0.09,1.10 \pm 0.06,0.85 \pm 0.05$ and $0.15 \pm 0.04 \mathrm{~cm}$ in the $\mathrm{ALDH}^{+} \mathrm{CD} 44^{+} \mathrm{CD} 24^{- \text {llow }}, \mathrm{ALDH}^{+}$and $\mathrm{CD} 44^{+} \mathrm{CD} 24^{-/ \text {low }}$ sub-populations, and the control group, respectively. Statistical analysis demonstrated that the tumorigenic abilities of the cells in the three sub-populations were significantly increased compared with the control group $(\mathrm{P}<0.05)$. The $\mathrm{ALDH}^{+} \mathrm{CD} 44^{+} \mathrm{CD} 24^{-/ \text {low }}$ sub-population exhibited the strongest tumor formation ability, and the tumor length was significantly increased compared with the other two sub-populations $\left(\mathrm{ALDH}^{+} \mathrm{CD} 44^{+} \mathrm{CD} 24^{- \text {llow }}\right.$ vs.
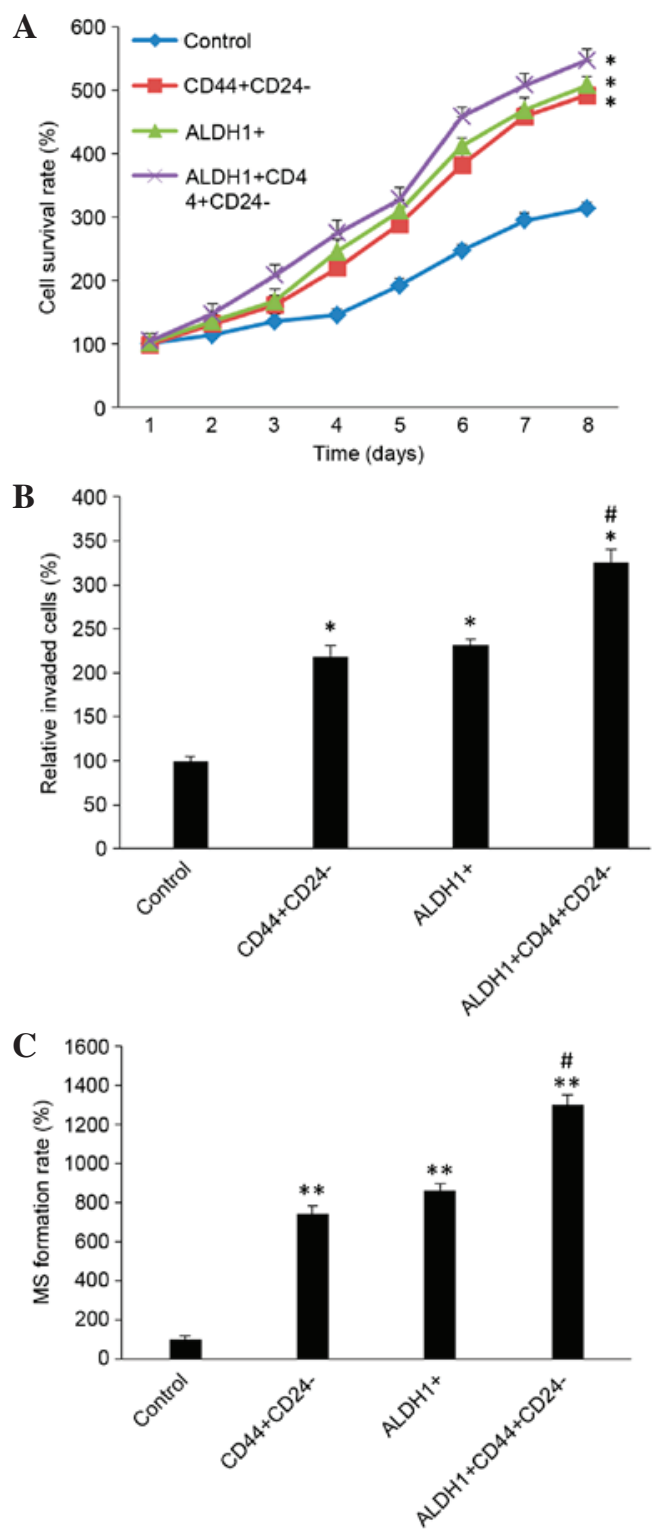

Figure 4. Proliferation and invasion profiles of different subgroup cells. (A) Cell growth curve of each subgroup cells after culture for 8 days. (B) Difference in invasion and migration ability of each cell sub-population by Transwell assay. (C) Comparison of MS formation rates in each sub-population after 8 days in serum-free suspension culture. ${ }^{*} \mathrm{P}<0.05,{ }^{* *} \mathrm{P}<0.01$, vs. control; ${ }^{\prime} \mathrm{P}<0.05, \mathrm{ALDH} 11^{+} \mathrm{CD} 44^{+} \mathrm{CD} 24^{-/ \text {low }}$ vs. $\mathrm{ALDH} 1^{+}$and $\mathrm{CD} 44^{+} \mathrm{CD} 24$. ALDH1, aldehyde dehydrogenase 1; MS, mammosphere. 
A

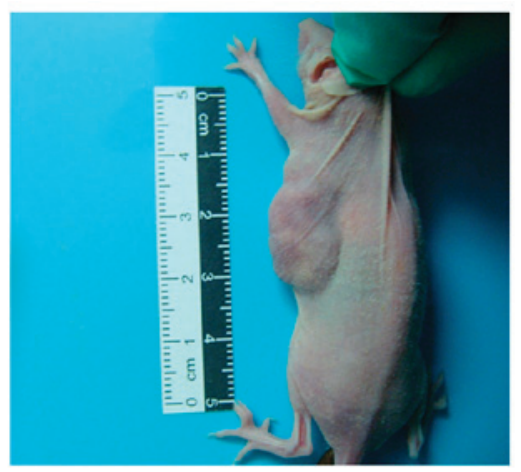

C

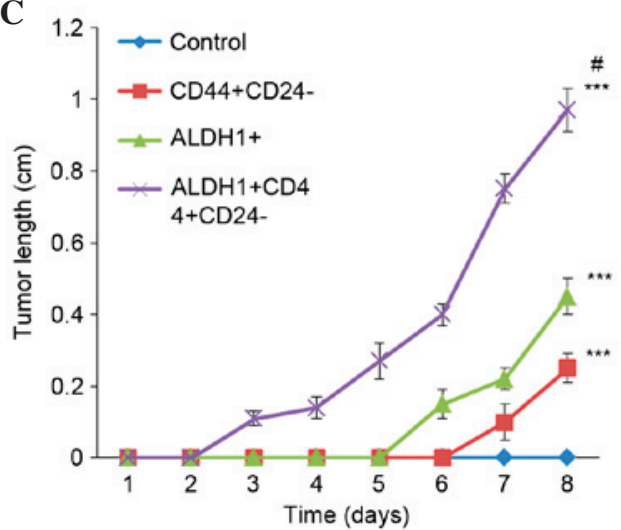

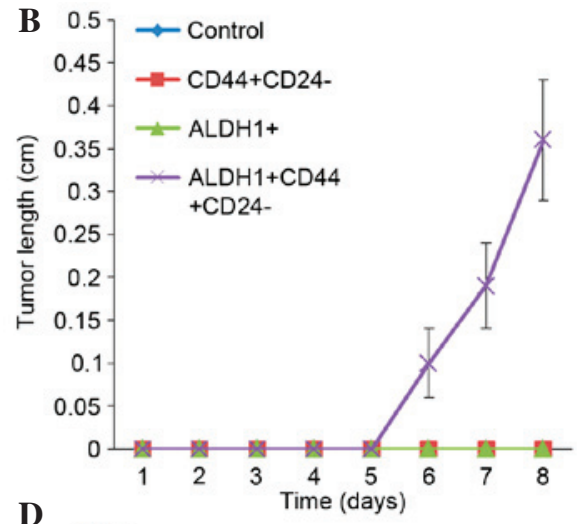

D

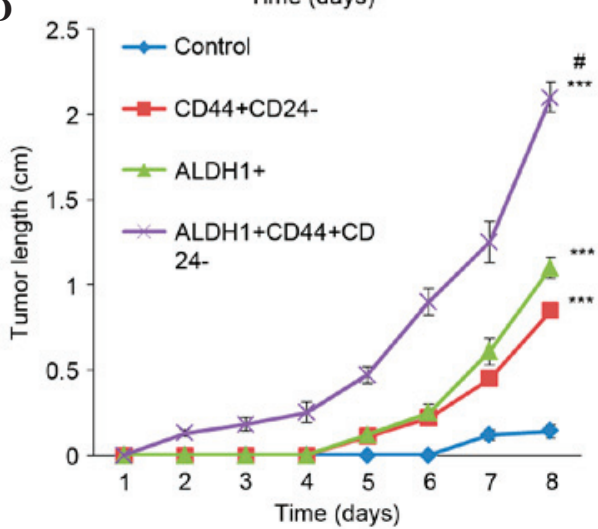

Figure 5. (A) Typical tumor-bearing nude mice after 8 weeks (A) and the growth curves of 4 groups injected with different numbers of tumor cells in nude mice for 8 weeks (n=5). (B) 500 cells/mouse, (C) 5,000 cells/mouse and (D) 50,000 cells/mouse. ${ }^{~} \mathrm{P}<0.05$, ALDH1 ${ }^{+} \mathrm{CD} 44^{+} \mathrm{CD} 24^{-/ \mathrm{low}}$ vs. ALDH1 ${ }^{+}$and CD44 ${ }^{+} \mathrm{CD} 24{ }^{-}$; ${ }^{* * *} \mathrm{P}<0.01$, vs. control. ALDH1, aldehyde dehydrogenase 1 .

$\mathrm{CD} 44^{+} \mathrm{CD} 24^{- \text {llow }}, \mathrm{P}=0.0074 ; \mathrm{ALDH}^{+} \mathrm{CD} 44^{+} \mathrm{CD} 24^{- \text {llow }}$ vs . $\left.\mathrm{ALDH}^{+}, \mathrm{P}=0.0104\right)$, and the comparison among the three sub-populations were significantly different $(\mathrm{P}=0.010$; Fig. 5D).

\section{Discussion}

The CSC hypothesis has important implications for understanding the basic biology of tumorigenesis. Cells endowed with stem-like properties demonstrate self-renewal and high tumorigenic potential. Current cancer treatments based on tumor regression can kill differentiated tumor cells, while sparing the small CSC population (8). Therefore, the development of more effective cancer therapies may require the identification, isolation and characterization of CSCs.

In recent years, advances have been made in the research of stem cell markers, including the marker set of CD44/CD24 and ALDH1 (11-22) Based on the cell surface markers, Al-Hajj et al (11) isolated the carcinogenic sub-population in breast cancer cells. CD $44^{+} / \mathrm{CD} 24$ cells possessed the ability to develop into tumors, whereas the alternate phenotypes failed to form tumors in mice. Ginestier et al (4) observed that breast cancer cells with high ALDH1 activity were able to generate tumors in nude mice with low cell numbers. The previously reported percentages of $\mathrm{CD} 44^{+} / \mathrm{CD} 24^{-}$cells and $\mathrm{ALDH1} 1^{+}$vary widely (11-22). In the current study, $\mathrm{CD} 44^{+} \mathrm{CD} 24^{-/ \text {low }}$ breast cancer cells were isolated from fresh tissue at a proportion of $7.2 \%$ of the total cell population, and $\mathrm{ALDH} 1^{+}$cells at $4.6 \%$. By further sorting, an overlap in the two-sub-population cells was detected, with $1.5 \%$ of the total breast cancer cells exhibiting the $\mathrm{CD} 44^{+} \mathrm{CD} 24^{-/ \text {low }}$ phenotype and ALDH1 activity. Immunofluorescence experiments also confirmed the presence of these three sub-populations cells in human breast cancer. The immunohistochemical expression of ALDH1 and its used for clinical prognosis have also been widely explored. High AlDH1 expression is correlated with poor prognosis in various types of cancer (23-27). Additionally, by analyzing the $\mathrm{CD} 44^{+} \mathrm{CD} 24^{- \text {llow }}$, epithelial specific antigen ${ }^{+}, \mathrm{CD} 133^{+}$and other multiple stem cell markers, Hwang-Verslues et al (15) observed significant differences in the biological characteristics among breast cancer cells with different markers, including $\mathrm{CD} 44^{+} / \mathrm{CD} 24, \mathrm{ESA}^{+}$or $\mathrm{CD} 133^{+}$, and even in different pathological types.

By MTT assay and Transwell experiments, the current study demonstrated that there were evident increases in self-renewal, proliferation and invasion ability among the $\mathrm{CD} 44^{+} \mathrm{CD} 24^{- \text {/low }}$, $\mathrm{ALDH}^{+}$and $\mathrm{ALDH} 1^{+} \mathrm{CD} 44^{+} \mathrm{CD} 24^{-/ \mathrm{low}}$ cells compared with the unsorted control cells, and $\mathrm{ALDH} 11^{+} \mathrm{CD} 44^{+} \mathrm{CD} 24^{- \text {/low }}$ cells were the strongest. Additionally, mammospheres were formed when the cancer cells were cultured in serum-free medium, and after continuous passage culture, they can produce new mammospheres. The difference of self-renewal capacity among these cell populations was also clearly demonstrated. The mammosphere formation rate of ALDH $1^{+} \mathrm{CD} 44^{+} \mathrm{CD} 24^{- \text {-low }}$ cells was significantly increased compared with the other groups. Increased number and size of mammospheres, as demonstrated in the current study, reflects the typical self-renewal of breast CSCs (16).

Dey et al (17) reported that, after long period in serum-free culture, breast CSCs exhibit difficulties in maintaining their 
undifferentiated state. With increasing passages, a high-oxygen environment led to telomerase loss, resulting in the aging of stem cells and interfering with the stem cells phenotype, which caused decreased self-renewal ability of the stem cells. In the present study, the cells were, therefore, passaged only 1-2 times to avoid stem cell aging.

In the present study, experiments using a nude mouse tumor model demonstrated that $\mathrm{CD} 44^{+} \mathrm{CD} 24^{-/ \text {low }}, \mathrm{ALDH} 1^{+}$, and $\mathrm{ALDH} 1^{+} \mathrm{CD} 44^{+} \mathrm{CD} 24^{-/ \text {low }}$ breast cancer cells all exhibited tumorigenic ability, however, significant differences between the sub-populations was also observed. Inoculation with $500 \mathrm{ALDH}^{+} \mathrm{CD} 44^{+} \mathrm{CD} 24^{-/ \text {low }}$ cells formed tumors, whereas, 500 of the other sub-population or control cells did not generate tumors. ALDH $1{ }^{+} \mathrm{CD} 44^{+} \mathrm{CD} 24^{-/ \text {low }}$ cells formed tumors earliest after injection, indicating that this cell population possessed the strongest tumorigenicity. Thus, in-depth study of the biological characteristics of different subsets of breast CSCs may provide a reference for clinical research and tumor treatment.

Previous studies have demonstrated that tumorigenic $\mathrm{ALDH}^{+}$cells are biologically aggressive, and their presence tends to be associated with poor patient prognosis. $\mathrm{CD} 44^{+} / \mathrm{CD} 24^{-/ \text {low }}$ cells and $\mathrm{ALDH} 1^{+}$cells are more frequently detected in basal-like tumors (4-7). In the current study, the primary breast cancer cells were obtained from basal-like tumors. According to the preliminary experiments, ALDH1 ${ }^{+}$ cells were easily detected and isolated from basal-like cancers, however, it was difficult to obtain these cells from other types of tumor. Thus, the primary cells used in the present study were from patients with basal-like breast cancer. Therefore, effort should be made to investigate the expression of stem cell markers in other types of breast cancer.

In conclusion, $\mathrm{CD} 44^{+} / \mathrm{CD} 24^{-/ \text {low }}, \mathrm{ALDH}^{+}$, and $\mathrm{ALDH} 1^{+}$ $\mathrm{CD} 44^{+} / \mathrm{CD} 24^{-/ \text {low }}$ cells have stem/progenitor properties, and are capable of self-renewal and generating tumors. There are distinct biological properties among the three cell sub-population; $\mathrm{ALDH} 1{ }^{+} \mathrm{CD} 44^{+} / \mathrm{CD} 24^{-/ \text {low }}$ cells exhibit the strongest self-renewal, proliferation, invasion and tumorigenic capacity, indicating that these sub-populations with different markers may potentially not originate from the same stem cells, which is helpful to understand the biological characteristics and heterogeneity of breast CSCs. Diverse phenotypes of $\mathrm{CD} 44^{+} / \mathrm{CD}_{2} 4^{-/ \text {low }}, \mathrm{ALDH}^{+}$and $\mathrm{ALDH}^{+} \mathrm{CD} 44^{+} / \mathrm{CD} 24^{-/ \text {low }}$ may be used to isolate and identify breast CSCs with distinct levels of heterogeneity, which display distinct biological characteristics. As $\mathrm{ALDH} 1^{+} \mathrm{CD} 44^{+} / \mathrm{CD} 24^{-/ \text {low }}$ cells exhibited the strongest stem-like properties, it may be useful as a more specific stem cell marker. The utilization of reliable biomarkers to distinguish the breast CSC pool will be important in the development of specific target therapies for breast cancer.

\section{Acknowledgements}

This work was supported by Hubei Provincial Health Department (grant no. JX4A07).

\section{References}

1. Ferlay J, Shin HR, Bray F, Forman D, Mathers C and Parkin DM: Estimates of worldwide burden of cancer in 2008: GLOBOCAN 2008. Int J Cancer 127: 2893-2917, 2010.
2. Shackleton M, Quintana E, Fearon ER and Morrison SJ: Heterogeneity in cancer: Cancer stem cells versus clonal evolution. Cell 138: 822-829, 2009.

3. Sottoriva A, Verhoeff JJ, Borovski T, McWeeney SK, Naumov L, Medema JP, Sloot PM and Vermeulen L: Cancer stem cell tumor model reveals invasive morphology and increased phenotypical heterogeneity. Cancer Res 70: 46-56, 2010.

4. Ginestier C, Hur MH, Charafe-Jauffret E, Monville F, Dutcher J, Brown M, Jacquemier J, Viens P, Kleer CG, Liu S, et al: ALDH1 is a marker of normal and malignant human mammary stem cells and a predictor of poor clinical outcome. Cell Stem Cell 1: 555-567, 2007.

5. Morimoto K, Kim SJ, Tanei T, Shimazu K, Tanji Y, Taguchi T, Tamaki Y, Terada N and Noguchi S: Stem cell marker aldehyde dehydrogenase 1-positive breast cancers are characterized by negative estrogen receptor, positive human epidermal growth factor receptor type 2, and high Ki67 expression. Cancer Sci 100: 1062-1068, 2009.

6. Deng S, Yang X, Lassus H, Liang S, Kaur S, Ye Q, Li C, Wang LP, Roby KF, Orsulic S, et al: Distinct expression levels and patterns of stem cell marker, aldehyde dehydrogenase isoform 1 (ALDH1), in human epithelial cancers. PLoS One 5: e10277, 2010

7. Croker AK, Goodale D, Chu J, Postenka C, Hedley BD, Hess DA and Allan AL: High aldehyde dehydrogenase and expression of cancer stem cell markers selects for breast cancer cells with enhanced malignant and metastatic ability. J Cell Mol Med 13: 2236-2252, 2009.

8. Wicha MS, Liu S and Dontu G: Cancer stem cells: An old idea-a paradigm shift. Cancer Res 66: 1883-1890; discussion 1895-1896, 2006.

9. Stingl J, Eirew P, Ricketson I, Shackleton M, Vaillant F, Choi D, Li HI and Eaves CJ: Purification and unique properties of mammary epithelial stem cells. Nature 439: 993-997, 2006.

10. Dontu G, Abdallah WM, Foley JM, Jackson KW, Clarke MF, Kawamura MJ and Wicha MS: In vitro propagation and transcriptional profiling of human mammary stem/progenitor cells. Genes Dev 17: 1253-1270, 2003.

11. Al-Hajj M, Wicha MS, Benito-Hernandez A, Morrison SJ and Clarke MF: Prospective identification of tumorigenic breast cancer cells. Proc Natl Acad Sci USA 100: 3983-3988, 2003.

12. Bane A, Viloria-Petit A, Pinnaduwage D, Mulligan AM, O'Malley FP and Andrulis IL: Clinical-pathologic significance of cancer stem cell marker expression in familial breast cancers. Breast Cancer Res Treat 140: 195-205, 2013.

13. Reya T, Morrison SJ, Clarke MF and Weissman IL: Stem cells, cancer, and cancer stem cells. Nature 414: 105-111, 2001.

14. Ponti D, Costa A, Zaffaroni N, Pratesi G, Petrangolini G, Coradini D, Pilotti S, Pierotti MA and Daidone MG: Isolation and in vitro propagation of tumorigenic breast cancer cells with stem/progenitor cell properties. Cancer Res 65: 5506-5511, 2005.

15. Hwang-Verslues WW, Kuo WH, Chang PH, Pan CC, Wang HH, Tsai ST, Jeng YM, Shew JY, Kung JT, Chen CH, et al: Multiple lineages of human breast cancer stem/progenitor cells identified by profiling with stem cell markers. PLoS One 4: e8377, 2009.

16. Phillips TM, McBride WH and Pajonk F: The response of CD24(-/low)/CD44+ breast cancer-initiating cells to radiation. J Natl Cancer Inst 98: 1777-1785, 2006.

17. Dey D, Saxena M, Paranjape AN, Krishnan V, Giraddi R, Kumar MV, Mukherjee G and Rangarajan A: Phenotypic and functional characterization of human mammary stem/progenitor cells in long term culture. PLoS One 4: e5329, 2009.

18. Ueda K, Ogasawara S, Akiba J, Nakayama M, Todoroki K, Ueda K, Sanada S, Suekane S, Noguchi M, Matsuoka K and Yano H: Aldehyde dehydrogenase 1 identifies cells with cancer stem cell-like properties in a human renal cell carcinoma cell line. PLoS One 8: e75463, 2013.

19. Rasper M, Schäfer A, Piontek G, Teufel J, Brockhoff G, Ringel F, Heindl S, Zimmer C and Schlegel J: Aldehyde dehydrogenase 1 positive glioblastoma cells show brain tumor stem cell capacity. Neuro Oncol 12: 1024-1033, 2010.

20. Mieog JS, de Kruijf EM, Bastiaannet E, Kuppen PJ, Sajet A, de Craen AJ, Smit VT, van de Velde CJ and Liefers GJ: Age determines the prognostic role of the cancer stem cell marker aldehyde dehydrogenase-1 in breast cancer. BMC Cancer 12: 42, 2012. 
21. Kuroda T, Hirohashi Y, Torigoe T, Yasuda K, Takahashi A, Asanuma H, Morita R, Mariya T, Asano T, Mizuuchi M, et al: ALDH1-high ovarian cancer stem-like cells can be isolated from serous and clear cell adenocarcinoma cells and ALDH1 high expression is associated with poor prognosis. PLoS One 8: e65158, 2013.

22. Lohberger B, Rinner B, Stuendl N, Absenger M, Liegl-Atzwanger $B$, Walzer SM, Windhager $R$ and Leithner A: Aldehyde dehydrogenase 1, a potential marker for cancer stem cells in human sarcoma. PLoS One 7: e43664, 2012.

23. Krause U, Ryan DM, Clough BH and Gregory CA: An unexpected role for a Wnt-inhibitor: Dickkopf-1 triggers a novel cancer survival mechanism through modulation of aldehyde-dehydrogenase-1 activity. Cell Death Dis 5: e1093, 2014.
24. Lohberger B, Stuendl N, Wolf E, Liegl-Atzwanger B, Leithner A and Rinner B: The novel myxofibrosarcoma cell line MUG-Myx1 expresses a tumourigenic stem-like cell population with high aldehyde dehydrogenase 1 activity. BMC Cancer 13: 563, 2013.

25. Wegman-Points LJ, Teoh-Fitzgerald ML, Mao G,Zhu Y,Fath MA, Spitz DR and Domann FE: Retroviral-infection increases tumorigenic potential of MDA-MB-231 breast carcinoma cells by expanding an aldehyde dehydrogenase (ALDH1) positive stem-cell like population. Redox Biol 2: 847-854, 2014.

26. Kim YS, Jung MJ, Ryu DW and Lee CH: Clinicopathologic characteristics of breast cancer stem cells identified on the basis of aldehyde dehydrogenase 1 expression. J Breast Cancer 17: 121-128, 2014.

27. Zhou W, Yang Y, Gu Z, Wang H, Xia J, Wu X, Zhan X, Levasseur D, Zhou Y, Janz S, et al: ALDH1 activity identifies tumor-initiating cells and links to chromosomal instability signatures in multiple myeloma. Leukemia 28: 1155-1158, 2014. 